\title{
IN-VITRO ANTIOXIDANT ACTIVITY OF CANNA INDICA EXTRACTS USING DIFFERENT SOLVENT SYSTEM
}

\author{
RAJAT SINGH ${ }^{1 *}$, RAKESH KUMAR BACHHETI ${ }^{1}$, SAINI CK ${ }^{1}$, UTKARSH SINGH $^{2}$ \\ ${ }^{1}$ Department of Chemistry, Graphic Era University, Dehradun, Uttarakhand, India. ${ }^{2}$ Department of Biotechnology, Sai Institute of \\ Paramedical and Allied Sciences, Dehradun, Uttarakhand, India. Email: rajatbiotech07@gmail.com
}

Received: 06 January 2016, Revised and Accepted: 27 January 2016

\section{ABSTRACT}

Objective: To investigate the antimicrobial and antidiabetic potential of Canna indica plant extracts.

Methods: In the present research work, the selected plant, i.e., $C$. indica L. Cannaceae was collected, dried and extracted with different solvents. Different tests were performed for the presence of different phytochemicals. The antimicrobial activity was determined by agar well-diffusion method. The extracts were evaluated for antidiabetic activity using alpha-amylase and alpha-glucosidase enzyme inhibition method.

Results: The findings of this study indicate that $C$. indica extracts contain secondary metabolites which have potent antimicrobial and antidiabetic activities comparable to standard drugs.

Conclusion: This information may help to develop potent bioactive compound(s) in the pharmaceutical industry for the development of drugs.

Keywords: Antimicrobial activity, Antidiabetic activity, Canna indica, Phytochemical analysis, Soxhlet extraction

(C) 2016 The Authors. Published by Innovare Academic Sciences Pvt Ltd. This is an open access article under the CC BY license (http://creativecommons. org/licenses/by/4. 0/) DOI: http://dx.doi.org/10.22159/ajpcr.2016.v9i6.10583

\section{INTRODUCTION}

The use of plants for treating diseases is as old as the human species. All over the globe, the use of medicinal plants has significantly supported primary health care [1]. From 250 to 500 thousand plant species are estimated to exist on the planet, and only between $1 \%$ and $10 \%$ are used as food by humans and other animals [2]. Plants synthesize many components, which act as defensive agent, helping to protect them from microbial infection and other diseases. Those compounds are bioactive and can be medicinal, intoxicating or toxic depending on circumstance. Several plants species have been tested for antimicrobial properties, but vast majorities have not yet been adequately evaluated [3] Various studies have been published, investigating the antifungal and antibacterial activities of plant-derived compounds against a range of pathogens [4-8]. Different substances have been identified in medicinal plants which are believed to be the antimicrobial agent, and these include different forms of alkaloids, diterpenes, saponins, flavonoids, sterols, quinines, different forms of other proteins as well as lipids [9] Diabetes mellitus is a common and very prevalent disease affecting the citizens of both developed and developing countries. It is estimated that $25 \%$ of the world population is affected by this disease [10]. The herbal drugs with antidiabetic activity are yet to be commercially formulated as modern medicines, even though they have been acclaimed for their therapeutic properties in the traditional systems of medicine [11].

Canna Linn. (Cannaceae) is a genus of herbs with rhizomatous rootstocks, distributed in the tropics and subtropics particularly of the western hemisphere. Canna indica L. is commonly known as Indian shot or Canna lily. It is extensively used in constructed wetland for removal of organic pollutants, nitrogen, phosphorous, and heavy metals [12-13]. In folkloric medicine, root decoction is used for the treatment of fever, dropsy, and dyspepsia. Seed juice is used to relieve earaches. The leaves of $C$. indica showed antimicrobial activity [14], analgesic activity, and the rhizomes showed a good anthelmintic activity against Pheretima posthuma [15]. The flower is said to cure eye diseases and shows antibacterial activity [16]. Flowers contain lutein, ß-carotene, and violaxanthin. Its leaves have chemical constituents such as lignin, furfural, and hemicelluloses. While rhizomes have 5,8 - henicosdine, tetracosane, tricosane $[17,18]$. The water extract of rhizomes of
C. indica has been reported to have HIV-1 reverse transcriptase inhibitory activity [19] while its essential oil shows antibacterial activity [20]. Methanolic extract of aerial parts of $C$. indica shows antioxidant activity [21]. Anthocyanins and methylated anthocyanin glycosides were also isolated from $C$. indica flowers [22,23]. In this study, we determine the antioxidant activity of $C$. indica extracts which may help to develop potent bioactive compound(s) in the pharmaceutical industry for the development of drugs.

\section{METHODS}

Collection and identification of plant material

The fresh aerial part of the plant $C$. indica $\mathrm{L}$. Cannaceae was collected from a local herbal garden in Dehradun. The plant sample was authenticated by Botancal Survey of India, Dehradun with the accession no. 113531 . The plant sample was dried in shed at room temperature and crushed to coarse powder.

\section{Preparation of extracts}

The dry leaves powder was subjected to successive soxhlet extraction with different solvents in increasing order of polarity (i.e., Petroleum Ether $<$ Chloroform < Ethanol). In this method of soxhlet extraction, a small volume of hot liquid is made to evaporate through a column again and again by heating and subsequent condensation. Thus, the same quantity of menstruum is recycled every time, and complete extraction is achieved with a very small volume of menstruum [24,25].

- Percentage yield of the crude extracts were calculated with the formula:

Percentage of yield $=\frac{\text { Weight of extract }(\mathrm{gm})}{\text { Weight of power are taken }(\mathrm{gm})} \times 100$

Phytochemical analysis of the extracts

Different tests were performed for the presence of different phytochemicals according to Lamaeswari and Ananthi (2012) [26].

\section{Test for carbohydrates}

For $2 \mathrm{ml}$ of extract, 2 drops of Molisch's reagent was added and shaken well $2 \mathrm{ml}$ of concentrated $\mathrm{H}_{2} \mathrm{SO}_{4}$ was added on the sides of the test tube. 
A reddish violet ring appeared at the junction of two layers immediately indicated the presence of carbohydrates.

\section{Test for proteins}

For $2 \mathrm{ml}$ of protein solution, $1 \mathrm{ml}$ of $40 \% \mathrm{NaOH}$ solution and 1-2 drops of $1 \% \mathrm{CuSO}_{4}$ solution was added. A violet color indicated the presence of peptide linkage of the molecule.

\section{Test for amino acids}

For $2 \mathrm{ml}$ of sample, added $2 \mathrm{ml}$ of ninhydrin reagent and kept in water bath for 20 minutes. The appearance of purple color indicated the presence of amino acids the sample.

\section{Test for steroids}

About $2 \mathrm{ml}$ of acetic anhydride was added to $0.5 \mathrm{~g}$ of an ethanolic extract of sample with $2 \mathrm{ml}$ of $\mathrm{H}_{2} \mathrm{SO}_{4}$. The color change from violet to blue or green indicated the presence of steroids.

\section{Test for alkaloids}

For the extract, added $1 \% \mathrm{HCl}$ and 6 drops of Mayer's regent and Dragendroff's reagent. An organic precipitate indicated the presence of alkaloids in the sample.

\section{Test for flavonoids}

About $5 \mathrm{ml}$ of dilute ammonia solution were added to a portion of aqueous filtrate of plant extract followed by addition of concentrated $\mathrm{H}_{2} \mathrm{SO}_{4}$. A yellow coloration is observed which confirms the presence of flavonoids and it disappears on standing.

\section{Test for tannins}

About $5 \mathrm{ml}$ of extract was added to few drops of $1 \%$ lead acetate. A yellow precipitate indicated the presence of tannins.

\section{Test for terpenoids}

About $5 \mathrm{ml}$ of extract was treated with $2 \mathrm{ml}$ of chloroform and $3 \mathrm{ml}$ of concentrated $\mathrm{H}_{2} \mathrm{SO}_{4}$ to from a monolayer of reddish brown coloration of the interface was showed to from the positive result for the terpenoids.

\section{Determination of antimicrobial activity}

Source of micro-organisms

The organisms used were Staphylococcus epidermis MTCC 435, Micrococcus luteus MTCC106, Bacillus subtilis MTCC 441, Bacillus cereus MTCC 645, Staphylococcus aureus (clinical), Escherichia coli (clinical), Pseudomonas aeruginosa MTCC 424, Salmonella typhimurium MTCC 733, Klebsiella pneumoniae MTCC 109, Aspergillus flavus, Aspergillus niger, Fusarium and Nigrospora oryzae. The organisms were obtained from IMTECH, Chandigarh.

\section{Antibacterial assay}

The antibacterial activity of different extracts was determined by agar well-diffusion method. The molten Mullar-Hinton agar was added to pre-sterilized plates and $0.1 \mathrm{ml}$ of $12-16 \mathrm{hrs}$ incubated culture of bacterial species were spreaded over the agar plates before spreading cultures was adjusted to MacFarlean constant. Wells were bored into the medium using well puncher syringe. Extract and isolated essential oil were dissolved in $30 \%$ DMSO to prepare $100 \mu \mathrm{l} / \mathrm{ml}$ solution. $0.1 \mathrm{ml}$ of each solution was transferred in wells of different plates. The plates were then incubated at $37^{\circ} \mathrm{C}$ for $24 \mathrm{hrs}$ in BOD incubator. The diameter of the zone of inhibition was measured in millimeter and compared with zone of standard antibiotic solute [27]

\section{Antifungal assay}

The antifungal assay was also performed by the well diffusion method. The well diffusion assay was used to screen for antifungal activity this was accomplished by placing a known amount of the extract in a small well. The wells were punctured on potato dextrose agar growth medium containing a confluent lawn of fungi. The absence of fungal growth around the well containing the extracts, indicate that the plant extracts have antifungal activity against that particular fungus [27]

\section{Determination of antidiabetic activity}

The antidiabetic activity of $C$. indica extracts was determined by using alpha-amylase and alpha-glucosidase enzyme inhibition methods.

\section{Inhibition of alpha-amylase enzyme}

Starch solution $(0.1 \% \mathrm{w} / \mathrm{v})$ was prepared by stirring $0.1 \mathrm{~g}$ of potato starch in $100 \mathrm{ml}$ of $16 \mathrm{mM}$ of sodium acetate buffer. The enzyme solution was prepared by mixing $27.5 \mathrm{mg}$ of alpha-amylase in $100 \mathrm{ml}$ of distilled water. The colorimetric reagent was prepared by mixing sodium potassium tartrate solution and 3, 5 dinitrosalicylic acid solution at $96 \mathrm{mM}$ concentration. Both control and plant extracts separately were added with starch solution and left to react with alpha- amylase solution under alkaline conditions at $25^{\circ} \mathrm{C}$. The reaction was measured after 3 minutes. The generation of maltose was quantified by the reduction of 3, 5 dinitrosalicylic acid to 3- amino-5- nitrosalicylic acid. This reaction is detectable at $540 \mathrm{~nm}$ [28].

\section{Inhibition of alpha-glucosidase enzyme}

The inhibitory activity of alpha-glucosidase enzyme was determined by incubating $1 \mathrm{ml}$ solution of starch substrate $(2 \% \mathrm{w} / \mathrm{v}$ maltose or sucrose) with $0.2 \mathrm{M}$ Tris buffer $\mathrm{pH} 8.0$ and plant extracts separately for 5 minutes at $37^{\circ} \mathrm{C}$. The reaction was initiated by adding $1 \mathrm{ml}$ of alphaglucosidase enzyme $(1 \mathrm{U} / \mathrm{ml})$ to it followed by incubation for 40 minutes at $35^{\circ} \mathrm{C}$. Then, the reaction was terminated by the addition of $2 \mathrm{ml}$ of $6 \mathrm{~N}$ $\mathrm{HCl}$. Then, the intensity of the color was measured at $540 \mathrm{~nm}$ [29].

\section{RESULTS}

\section{$\%$ yield of the extracts}

Solvents on the basis of increasing polarity were used for the extraction. It was observed that the highest percentage yield of extract was found in water $(9.48 \%)$ followed by chloroform $(3.67 \%)$, petroleum ether (2.52\%), and ethanol (1.92\%) (Table 1).

\section{Phytochemical analysis of the extracts}

The results obtained for qualitative screening of phytochemicals in the extracts are presented in Table 2. In all, more phytochemicals were found in the ethanolic extract. Remarkably steroids are absent in ethanolic extract.

\section{Determination of antimicrobial activity}

The antimicrobial activity of extracts from $C$. indica could be attributed to the broad spectrum of bioactive chemical compounds. The study showed remarkable antimicrobial activity. The plant has potent antibacterial activity with zone of inhibition of $21 \mathrm{~mm}$ in the case of petroleum ether extract against $M$. luteus, followed by $20 \mathrm{~mm}$ in ethanolic extract against M. luteus, S. aureus and K. pneumoniae. P. aeruginosa showed minimum activity $(11 \mathrm{~mm})$ in the ethanolic extract.

Among the selected fungal strains the highest activity was seen for A. niger $(16 \mathrm{~mm})$ in the ethanolic extract. The water extract do not show any activity against any of the selected microbes (Table 3 ).

Table 1: \% yield of the exracts

\begin{tabular}{lll}
\hline S.N & Solvent used & Canna indica (\%) \\
\hline 1 & Petroleum ether & 2.52 \\
2 & Chloroform & 3.67 \\
3 & Ethanol & 1.92 \\
4 & Water & 9.48 \\
\hline
\end{tabular}

C. indica: Canna indica 
Table 2: Phytochemical analysis of the exracts

\begin{tabular}{|c|c|c|c|c|c|c|}
\hline Phytochemical present & Plant & Pet ether & $\mathrm{CHCl}_{3}$ & EtOH & Water & Previous research \\
\hline Carbohydrates & C. indica & - & - & + & + & +ve in flower [26] \\
\hline Protein and amino acids & C. indica & - & - & + & + & -ve in flower [26] \\
\hline Steroids & C. indica & + & + & - & - & \\
\hline Alkaloids & C. indica & + & + & + & - & +ve in flower [26] \\
\hline Phenolics and flavonoids & C. indica & - & + & + & - & +ve in flower [26] \\
\hline Tannins & C. indica & - & - & + & + & \\
\hline Terpenoids & C. indica & - & - & + & + & +ve in flower [26] \\
\hline
\end{tabular}

C. indica: Canna indica

Table 3: Determination of antimicrobial activity

\begin{tabular}{|c|c|c|c|c|c|}
\hline Bacterial Strain & Petroleum ether & Chloroform & Ethanol & Water & Ampicillin \\
\hline Micrococcus luteus & $21 \pm 0.02$ & - & $20 \pm 0.02$ & - & $18 \pm 0.02$ \\
\hline Staphylococcus aureus & $20 \pm 0.02$ & - & $18 \pm 0.02$ & - & $18 \pm 0.02$ \\
\hline Pseudomonas aeruginosa & $13 \pm 0.01$ & - & $11 \pm 0.01$ & - & $10 \pm 0.01$ \\
\hline Salmonella typhimurium & - & - & - & - & $11 \pm 0.01$ \\
\hline Klebsiella pneumoniae & $20 \pm 0.02$ & $19 \pm 0.02$ & $19 \pm 0.02$ & - & $17 \pm 0.02$ \\
\hline Escherichia coli & $15 \pm 0.01$ & $13 \pm 0.01$ & $12 \pm 0.01$ & - & $12 \pm 0.01$ \\
\hline Streptococcus mutans & - & - & $12 \pm 0.01$ & - & $14 \pm 0.01$ \\
\hline Fungal Strains & & & & & Ketaconazole \\
\hline Aspegillus niger & - & $12 \pm 0.01$ & $16 \pm 0.02$ & - & $24 \pm 0.02$ \\
\hline Aspergillus flavus & - & - & $12 \pm 0.01$ & - & $21 \pm 0.02$ \\
\hline Fusarium solani & - & - & $14 \pm 0.02$ & - & $19 \pm 0.02$ \\
\hline Nigrospora oryzae & - & - & $10 \pm 0.01$ & - & $22 \pm 0.02$ \\
\hline
\end{tabular}

All values shows diameter of zone of inhibition in mm. A. niger: Aspegillus niger, A. flavus: Aspergillus flavus, F. solani: Fusarium solani, N. oryzae: Nigrospora oryzae

Table 4: Percent reduction in $\alpha$ amylase enzyme activity by extracts and positive control

\begin{tabular}{ll}
\hline Extracts & $\begin{array}{l}\text { Percent reduction in } \\
\boldsymbol{\alpha} \text { amylase enzyme } \\
\text { activity (\%) }\end{array}$ \\
\hline Canna indica petroleum ether extract & 73.5 \\
Canna indica chloroformic extract & 72.6 \\
Canna indica ethanolic extract & 80.0 \\
Canna indica water extract & 56.34 \\
Glycinamide (+ve control) & 90.56 \\
\hline
\end{tabular}

C. indica: Canna indica

Table 5: Percent reduction in $\alpha$ glucosidase enzyme activity by extracts and positive control

\begin{tabular}{ll}
\hline Extracts & $\begin{array}{l}\text { Percent reduction in } \\
\text { a glucosidase enzyme } \\
\text { activity (\%) }\end{array}$ \\
\hline Canna indica petroleum ether extract & 75 \\
Canna indica chloroformic extract & 73 \\
Canna indica ethanolic extract & 82 \\
Canna indica water extract & 64 \\
Glycinamide (+ve control) & 92 \\
\hline
\end{tabular}

C. indica: Canna indica

\section{Determination of antidiabetic activity}

The antidiabetic activity of the $C$. indica extracts was assayed by reduction in $\alpha$ amylase and $\alpha$ glucosidase enzyme activity. In $\alpha$ amylase enzyme activity, the maximum reduction was found in the ethanolic extract $(80.0 \%)$ followed by petroleum ether extract $(73.5 \%)$ and chloroform extract $(72.6 \%)$. The minimum reduction was found in water extract (56.34\%) (Table 4). In $\alpha$ glucosidase enzyme activity, the maximum reduction was found in ethanolic extract $(82.0 \%)$ followed by petroleum ether extract (75.0\%) and chloroform extract (73.0\%). The minimum reduction was found in water extract (64.0\%) (Table 5). Both the activities were compared with the standard antidiabetic agent glycinamide as +ve control.

\section{DISCUSSION}

According to Tiwari et al. (2011), the factors affecting the choice of solvent are the quantity of phytochemicals to be extracted, rate of extraction, diversity of different compounds extracted, diversity of inhibitory compounds extracted, ease of subsequent handling of the extracts, toxicity of the solvent in the bioassay process, potential health hazard of the extractant [30]. According to Gaur et al. (2014), the extract shows good antibacterial activity against $S$. aureus, B. subtilis and mild active against E. coli [31]. According to George (2014), the antimicrobial activity of the oil showed significant inhibitory activity against the human pathogenic bacteria and no activity was observed against the fungi $A$. niger and Fusarium oxysporum [32]. Purintrapiban et al. (2006) also reported the effects of $C$. indica extracts, which has been used as a traditional medicine for treating diabetes on glucose transport activity, which was evaluated in cultured L8 muscle cells. The aqueous extract of $C$. indica root (CI) at doses of $0.1-0.5 \mathrm{mg} / \mathrm{ml}$, which contains total phenolic compounds equivalent to $6-30 \mathrm{~m} \mathrm{~g}$ of catechin caused a dose and time-dependent induction of 2-deoxy-[3H] glucose (2-DG) uptake activity [33].

\section{CONCLUSION}

C. indica (L.) is a well-known plant with less known scientific data. The folkloric medicinal value imparts tremendous value to this herb. The qualitative analysis revealed the presence of the phytochemical such as carbohydrates, proteins, amino acids, steroids, alkaloids, phenolics, flavonoids, tannins, and terpenoids. The present work shows that C. indica is a medicinal plant with anti-microbial and anti-diabetic activities which could be utilized in several medicinal applications because of its effectiveness. Therefore, there is wide scope for research in the direction of more medicinal activities of plant and to evaluate the pharmacological actions of the same incoming future.

\section{REFERENCES}

1. Maciel MA, Pinto AC, Veiga Jr VF, Grynberg NF, Echevarria A. Medicinal plants: The need for multidisciplinary scientific studies. Quim Nova 2002;25(3):429-38.

2. Cowan MM. Plant products as antimicrobial agents. Clin Microbiol Rev 1999;12(4):564-82. 
3. Azoro C. Antibacterial activity of crude extract of Azadirachta indica on Salmonella typhi. World J Biotechnol 2002;3:354-7.

4. Tassou C, Koutsoumanis K, Nychas GJ. Inhibition of Salmonella enteritidis and Staphylococcus aureus in nutrient broth by mint essential oil. Food Res Int 2000;33:273-80.

5. Friedman M, Henika PR, Mandrell RE. Bactericidal activities of plant essential oils and some of their isolated constituents against Campylobacter jejuni, Escherichia coli, Listeria monocytogenes, and Salmonella enterica. J Food Prot 2002;65(10):1545-60.

6. Momtaz S,Abdollahi M.An update on pharmacology of Satureja species; from antioxidant, antimicrobial, antidiabetes and anti-hyperlipidemic to reproductive stimulation. Int J Pharmacol 2010;6:346-53.

7. Ara N, Nur MH, Amran MS, Wahid MI, Ahmed M. In vitro antimicrobia and cytotoxic activities of leaves and flowers extracts from Lippia alba. Pak J Biol Sci 2009;12(1):87-90.

8. Manikandan S, Ganesapandian S, Singh M, Sangeetha N, Kumaraguru AK. Antimicrobial activity of seaweeds against multi drug resistant strains. Int J Pharmacol 2011;7:522-6.

9. Sofowora A. Medical Plant and Traditional Medicine in Africa. $2^{\text {nd }}$ ed. Ibadan: Spectrum Books Limited Publisher; 1993. p. 134-56.

10. Maiti R, Jana D, Das UK, Ghosh D. Antidiabetic effect of aqueous extract of seed of Tamarindus indica in streptozotocin-induced diabetic rats. J Ethnopharmacol 2004;92(1):85-91.

11. Wadkar KA, Magdum CS, Patil SS, Naikwade NS. Antidiabetic potential and Indian medicinal plants. J Herbal Med Toxicol 2008;2:45-50.

12. DeBust TA, Peterson JE, Reddy KR, Use of aquatic and terrestrial plants for removing phosphorus from dairy wastewaters. Ecol Eng 1995;5:371-390.

13. Neralla S, Weaver RW, Varvel TW, Lesikar BJ, Phytoremediation and on-site treatment of septic effluents in sub-surface flow constructed wetlands. Environ Technol 1999;20:1139-46.

14. Abdullah E, Raus RA, Jamal P. Extraction and evaluation of antibacterial activity from selected flowering plants. Ame Med J 2012;3(1):27-32.

15. Nirmal SA, Shelke SM, Gagare PB, Jadhav PR, Dethe PM. Antinociceptive and anthelmintic activity of Canna indica. Nat Prod Res 2007;21(12):1042-7.

16. Lamaeswari G, Ananthi T. TLC analysis and antibacterial activity of canna indica flowers. Int J Pharm Tech 2012;4(2):4268-79.

17. Deming RL, Tinoi J. Determination of major caratenoid constituents in petal extract of eight selected flowering in the North of Thailand. Chi J
Sci 2006;33(2):327-34

18. Kolhe NM, Nirmal SA, Pal SC, Nonpolar compounds from Canna indica rhizomes. Phys Chem Technol 2008;6(1):141-6.

19. Woradulayapinij W, Soonthornchareonnon N, Wiwat C. In vitro HIV type 1 reverse transcriptase inhibitory activities of Thai medicinal plants and Canna indica L. rhizomes. J Ethnopharmacol 2005;101(1-3):84-9.

20. Indrayan AK, Bhojakb NK, Kumara N, Gaur A. Chemical composition and antimicrobial activity of the essential oil from the rhizome of Canna indica linn. Ind J Chem 2011;50B(08):1136-9.

21. Joshi YM, Kadam VJ, Kaldhone NK. In-vitro antioxidant activity of methanolic extract of aerial parts of Canna indica L. J Pharma Res 2009;2(11):1712-5.

22. Srivastava J, Vankar PS. Canna indica flower: New source of anthocyanins. Plant Physiol Biochem 2010;48(12):1015-9.

23. Srivastava J, Vankar PS. Methylated anthocyanidin glycosides from flowers of Canna indica. Carbohydr Res 2010;345(14):2023-9.

24. Kokate CK, Purohit AP, Gokhke SB. Text Book of Pharmacognosy. $3^{\text {rd }}$ ed. Pune: Nirali Prakashhan; 2005. p. 593-7.

25. Mukharjee PK. Quality Control of Herbal Drugs - An Approach to Evaluation of Botanicals. $1^{\text {st }}$ ed. New Delhi: Business Horizons Pharmaceutical Publication; 2002. p. 183-97.

26. Lamaeswari G, Ananthi T. Preliminary phytochemical screening and physiochemical characterization of Canna indica L. Int J Pharm Sci Res 2012;14(2):76-9.

27. Perez C, Pauli M, Bezerque P. An antibiotic assay by the well agar Method. Acta Biol Med Exp 1990;15:113-5.

28. Malik CP, Singh MB. Plant Enzymology and Histoenzymology. New Delhi: Kalyani Publishers; 1980. p. 278.

29. Krishnaveni S, Theymoli B, Sadasivam S. Phenol sulphuric acid method. Food Chem 1984;15:229.

30. Tiwari P, Kumar B, Kaur M, Kaur G, Kaur H. Phytochemical Screening and Extraction: A review. Int Pharm Sci 2011;1(1):98-106.

31. Gaur A, Boruah M, Tyagi DK. Antimicrobial potential of Canna indica Linn. Extracts against selected bacteria. J Environ Sci Toxi Food Technol 2014;8(8):22-5.

32. George J. Screening and antimicrobial activity of Canna indica against clinical pathogens bioactive. Int J Life Sci Edu Res 2014;2(3):85-8.

33. Purintrapiban J, Suttajit M, Forsberg NE. Differential activation of glucose transport in cultured muscle cells by polyphenolic compounds from Canna indica L. Root. Biol Pharm Bull 2006;29(10):1995-8. 